ISSN 0853-8697

\title{
RANCANG BANGUN MESIN PEMISAH DAGING KELAPA DARI TEMPURUNG
}

\author{
Ahmad Supriyadi \\ Jurusan Teknik Mesin Politeknik Negeri Semarang \\ Jl. Prof.H. Sudarto, SH Tembalang Semarang
}

\begin{abstract}
Coconut's endosperm separation process has been done manually in the home industry the process is that coconut fiber separation process by using short sword kind of crowbar, and coconut shell separation process by using short sword .

All of process uses human's hand ( manual). By the process, it will containt high accident risk it also needs long time and needs a lot of workers. A worker can reach 30 coconuts/hour in capacity only and there are part of coconut shell stick on coconut's endosperm although in minimum size. For separation process eficiency rises, needs mechanical separation process. Those by design and build "Endosperm separating machine ", which can produce clean and fullfill the home industry standart which has small fund. Design and build process starts by knowing force need for slice the coconut and force need for separating endosperm process by shape testing, slicer dimensions and separotor dimensions, machine mechanism, kind of motor, and power to run the process.

Endosperm separating machine completed by slicer and motored by electrical motor $1 / 2$ HP, $1450 \mathrm{rpm}$ by three steps transmition consist of belt, pulley for slicing process and gear box 1 : 40, bevel gear, for separation process. Capacity by using this machine, production capacity can reach 90 coconuts/hour with separation quality is better than manual process.
\end{abstract}

Keywords : coconut, coconut shell, separation, crowbar

\section{PENDAHULUAN}

Industri rumah tangga produksi minyak kelapa atau usaha jasa pemarutan dalam proses produksi pengambilan putih lembaga masih melalui proses pengupasan sabut dan pematikan tempurung yang dilakukan dengan cara manual, yaitu untuk proses pengupasan sabut menggunakan alat sejenis linggis (slumbat) atau dengan sebilah parang, dan untuk proses pematikan menggunakan parang berbentuk kampak. Kedua tahapan proses tersebut selain beresiko kecelakaan bagi operator juga banyak menguras tenaga dan waktu, dan hasil pematikan putih lembaga masih terdapat sisa tempurung yang menmpel, serta kapasitasnya hanya mencapai 30 buah kelapa/jam.

Proses pemisahan dengan cara manual dirasakan kurang efisien, oleh karena itu perlu perbaikan proses secara mekamis, yaitu dengan membuat mesin pemisah putih lembaga dari tempurungnya, agar kapasitas persatuan waktu dapat ditingkatkan dengan hasil pemisahan yang lebih baik dari cara manual yaitu putih lembaga bersih dari tempurung, dan pada akhirnya dapat menekan biaya produksi. 
Untuk mencapai tujuan yang dimaksud maka mesin dirancang dan dibuat dengan memperhatikan batasan-batasan sebagai berikut :

1. Mesin dirancang khusus untuk pemisah putih lembaga buah kelapa dari tempurung dengan hasil putih lembaga bersih dari tempurung.

2. Buah kelapa yang dapat diproses pada mesin yang dirancang berumur antara 341 - 413 hari.

3. Penggerak mesin menggunakan motor listrik $1 / 2 \quad H p$ putaran $1600 \mathrm{rpm}$, sehingga dapat dioperasikan pada industri rumah tangga yang bermodal kecil dan tidak menimbulkan pulusi udara.

4. Konstruksi mesin terdiri dari dua bagian kerja yaitu kerja pembelahan menggunakan perinsip gergaji dan kerja pemisahan putih lembaga dari tempurung menggunakan perinsip pencukilan, kedua konstruksi tersebut mekanismenya sederhana agar mudah dalam perawatan sehingga dapat menekan biaya produksi.

5. Mesin dioperasikan oleh satu orang tenaga kerja dan mudah dioperasikan, sehingga waktu pelatihan menjadi operator relatif singkat.

Gaya pembelah buah kelapa dan gaya tusuk antara putih lembaga dengan tempurung didapat dari hasil percobaan menggunakan metode :

a. Untuk gaya pembelah buah kelapa.

Buah kelapa digergaji dengan cara kedua ujung gergaji masing-masing dikaitkan pada neraca pegas (lihat gambar 1) maka dapat diketahui gaya yang dibutuhkan untuk membelah buah kelapa baik langkah gergaji maju maupun langkah mudur. Gambar 1 adalah sketsa teknis uji pembelahan buah kelapa dan tabel 1 merupakan data hasil pengujian. Sesuai hasil pengujian terlihat pada tabel 1 gaya pembelah maksimum adalah $F_{\text {Mak }}$ sebesar $47,5 \mathrm{kgf}$.

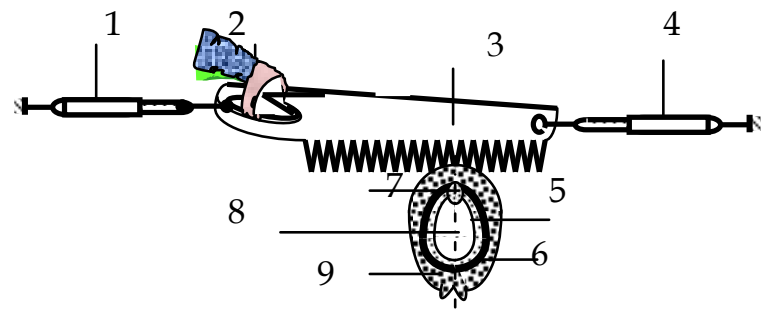

Gambar 1. Sketsa Mekanisme Pengujian Gaya Pembelah

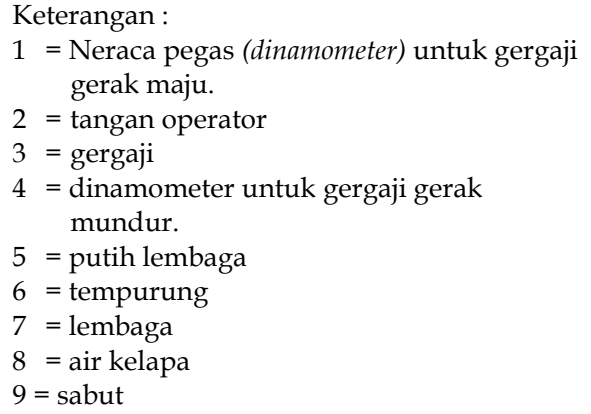

Keterangan :

$=$ tangan operator

= gergaj

dinamometer untuk gergaji gerak

$=$ putih lembaga

6 = tempurung

8 = air kelap

$9=$ sabut 
b. Untuk gaya tusuk antara putih lembaga dengan tempurung.

Antara putih lembaga dengan tempurung ditusuk menggunakan sebilah pisau bermata lancip atau sejenis linggis yang dikaitkan pada neraca pegas (lihat gambar 2. sketsa teknis pengujian gaya tusuk) maka dapat diketahui gaya tusuk yang dibutuhkan untuk mencukil putih lembaga dari tempurungnya. Gaya tusuk maksimum sesuai data hasil percobaan diperlihatkan pada tabel 2 adalah $\mathrm{F}_{\mathrm{T}}=47,5 \mathrm{kgf}$.
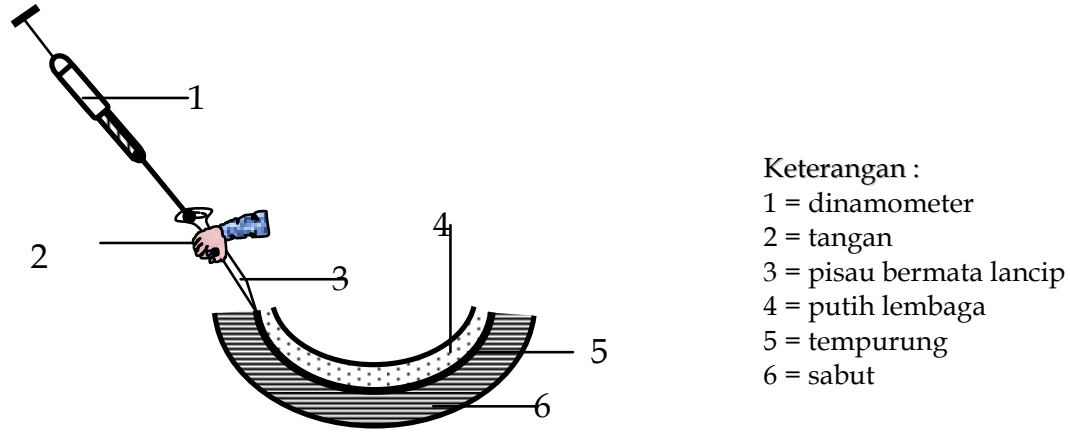

Gambar 2. Sketsa Mekanisme Pengujian Gaya Tusuk

Tabel 1. Gaya Pembelah Buah Kelapa Hasil Percobaan

\begin{tabular}{|c|c|c|c|c|c|}
\hline \multirow{2}{*}{$\begin{array}{c}\text { Jenis Kelapa } \\
\text { Umur buah (hari) }\end{array}$} & \multirow{2}{*}{$\begin{array}{c}\text { No } \\
\text { Sampel }\end{array}$} & \multicolumn{2}{|c|}{ Ukuran ( mm ) } & \multicolumn{2}{|c|}{ Gaya Pembelah (kgf) } \\
\hline & & Diameter & Panjang & Gerak Maju & Gerak Mundur \\
\hline \multirow{5}{*}{$\begin{array}{c}\text { Genjah } \\
341-413\end{array}$} & 1 & 134 & 200 & 30 & 27,5 \\
\hline & 2 & 132 & 188 & 25 & 30 \\
\hline & 3 & 134 & 188 & 30 & 25 \\
\hline & 4 & 136 & 200 & 27,5 & 25 \\
\hline & 5 & 134 & 202 & 28 & 27,5 \\
\hline \multirow{5}{*}{$\begin{array}{c}\text { Kopyor } \\
341-413\end{array}$} & 1 & 185 & 200 & 40 & 35 \\
\hline & 2 & 180 & 202 & 35 & 35 \\
\hline & 3 & 184 & 188 & 37,5 & 40 \\
\hline & 4 & 184 & 200 & 35 & 35 \\
\hline & 5 & 182 & 202 & 40 & 35 \\
\hline \multirow{5}{*}{$\begin{array}{c}\text { Hijau } \\
341-413\end{array}$} & 1 & 260 & 280 & 45 & 40 \\
\hline & 2 & 262 & 282 & 45 & 42,5 \\
\hline & 3 & 258 & 280 & 42,5 & 40 \\
\hline & 4 & 258 & 278 & 45 & 45 \\
\hline & 5 & 260 & 282 & 45 & 40 \\
\hline \multirow{5}{*}{$\begin{array}{c}\text { Kuning } \\
341-413\end{array}$} & 1 & 220 & 230 & 45 & 42,5 \\
\hline & 2 & 218 & 228 & 47,5 & 42,5 \\
\hline & 3 & 220 & 228 & 47,5 & 45 \\
\hline & 4 & 222 & 232 & 45 & 42,5 \\
\hline & 5 & 220 & 232 & 45 & 42,5 \\
\hline
\end{tabular}


Tabel 2. Gaya Tusuk Antara Putih Lembaga dan Tempurung Hasil Percobaan

\begin{tabular}{|c|c|c|c|c|}
\hline \multirow{2}{*}{$\begin{array}{c}\text { Jenis Kelapa } \\
\text { Imur buah (hari) }\end{array}$} & \multicolumn{3}{|c|}{ Ukuran ( mm ) } & \multirow[b]{2}{*}{ Gaya Tusuk ( kgf) } \\
\hline & $\begin{array}{c}\text { No } \\
\text { Sampel }\end{array}$ & $\begin{array}{c}\text { Tebal Putih } \\
\text { Lembaga }\end{array}$ & $\begin{array}{c}\text { Tebal } \\
\text { Tempurung }\end{array}$ & \\
\hline \multirow{5}{*}{$\begin{array}{c}\text { Genjah } \\
341-413\end{array}$} & 1 & 11 & 4 & 30 \\
\hline & 2 & 8 & 4 & 25 \\
\hline & 3 & 9 & 4 & 30 \\
\hline & 4 & 10 & 4 & 27,5 \\
\hline & 5 & 11 & 4 & 28 \\
\hline \multirow{5}{*}{$\begin{array}{l}\text { Kopyor } \\
341-413\end{array}$} & 1 & 10 & 3,5 & 40 \\
\hline & 2 & 11 & 4 & 35 \\
\hline & 3 & 10 & 3,5 & 37,5 \\
\hline & 4 & 10 & 3,5 & 35 \\
\hline & 5 & 10 & 4 & 40 \\
\hline \multirow{5}{*}{$\begin{array}{c}\text { Hijau } \\
341-413\end{array}$} & 1 & 14 & 4,5 & 45 \\
\hline & 2 & 13,5 & 4 & 45 \\
\hline & 3 & 14 & 4 & 42,5 \\
\hline & 4 & 14 & 4,5 & 45 \\
\hline & 5 & 14 & 4,5 & 45 \\
\hline \multirow{5}{*}{$\begin{array}{l}\text { Kuning } \\
341-413\end{array}$} & 1 & 8 & 4 & 45 \\
\hline & 2 & 8 & 4 & 47,5 \\
\hline & 3 & 9 & 3,5 & 47,5 \\
\hline & 4 & 7,5 & 4 & 45 \\
\hline & 5 & 7,5 & 4 & 45 \\
\hline
\end{tabular}

\section{METODE PERANCANGAN}

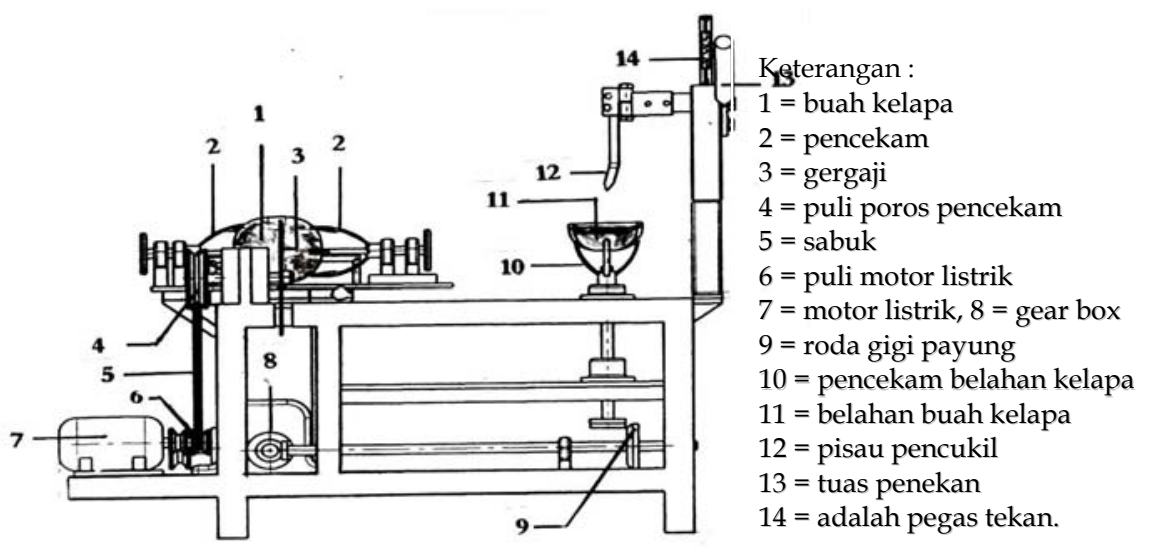

Gambar 3. Sketsa Mekanisme Kerja Mesin Pembelah Buah Kelapa dan Pemisah Putih Lembaga dari Tempurung 
a. Menentukan mekanisme kerja untuk proses pembelahan dan pencukilan. Gergaji berbentuk piringan (circle disk) berputar untuk membelah buah kelapa langsung digerakkan motor listrik melalui transmisi sabuk puli, dan buah kelapa dicekam pada dua sisi dengan pencekam yang masing-masing dilengkapi dengan pegas tekan. Sedangkan pencekam belahan buah kelapa hasil penggergajian juga digerakkan motor listrik yang sama tetapi melalui transmisi gear box dan roda gigi kerucut (payung.). Gambar 3 adalah sketsa konstruksi mesin pembelah buah kelapa dan pemisah putih lembaga dari tempurung.

b. Perhitungan hubungan kapasitas yang ingin dicapai dengan dimensi gergaji, dimensi buah kelapa dan gaya pembelah mengacu pada mekanisme kerja proses pembelahan. Hubungan diameter buah kelapa dengan diameter piringan gergaji menggunakan persamaan (1), dan sketsanya ditunjukkan oleh gambar 4.

$\mathrm{n}_{\mathrm{A}} \cdot \pi \cdot \mathrm{D}=\mathrm{d}[$ put $/$ det $]$
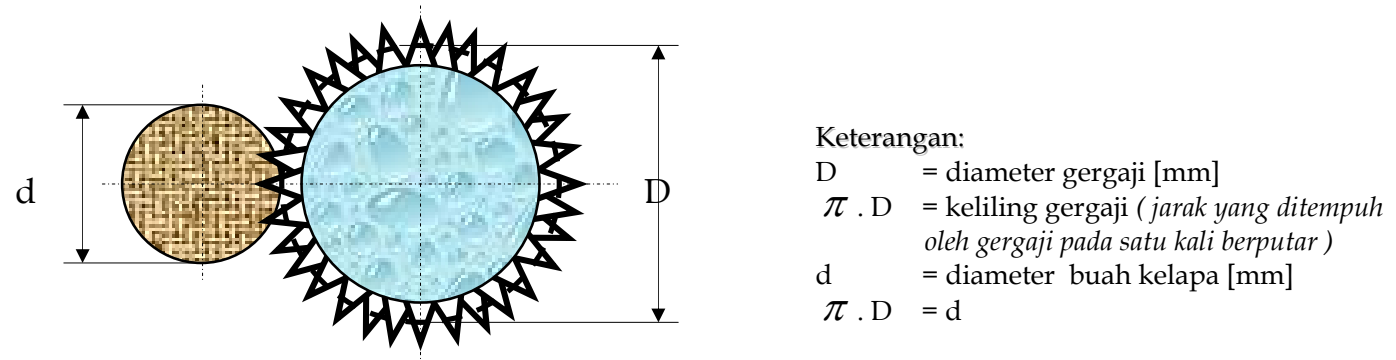

Gambar 4. Hubungan diameter buah kelapa dengan diameter gergaji

Untuk menghitung putaran piringan gergaji yang diperlukan dapat menggunakan persamaan (1), sedangkan daya yang diperlukan menggunakan persamaan (2).

$$
\mathrm{P}_{\mathrm{A}}=\frac{2 \pi \mathrm{n}_{\mathrm{A}} \mathrm{T}_{\mathrm{A}}}{60} \text { Watt }
$$

Keterangan :

$\mathrm{P}_{\mathrm{A}}=$ daya yang dibutuhkan untuk memutar gergaji [Watt]

$\mathrm{T}_{\mathrm{A}}=$ momen putar gergaji $[\mathrm{kgf} \mathrm{m}] \mathrm{n}_{\mathrm{A}}=$ putaran gergaji $[\mathrm{rpm}]$

Oleh karena gergaji seporos dengan puli nomor 4 yang berdiameter $\mathrm{D}_{4}$ maka putarannya sama dengan putaran gergaji yaitu $n_{4}=n_{A}$, demikian pula dayanya $\mathrm{P}_{4}=\mathrm{P}_{\mathrm{A}}$, sedangkan putaran pada puli nomor 6 menggunakan persamaan (3) dan daya pada puli 6 dengan persamaan (4). 


$$
\begin{aligned}
& \mathrm{n}_{6}=\frac{\mathrm{n}_{4} \cdot \mathrm{D}_{4}}{\mathrm{D}_{6}} \\
& \mathrm{P}_{6}=\frac{\mathrm{P}_{4}}{\eta_{\mathrm{A}}}
\end{aligned}
$$

c. Perhitungan hubungan kapasitas pencukilan yang diinginkan dengan dimensi buah kelapa dan gaya tusuk untuk menentukan daya dan putaran yang diperlukan pada proses pencukilan., kemudian hubungan dimensi bagian-bagian mesin dengan gaya-gaya yang berkerja sehingga daya dan putaran yang diperlukan penggerak dapat terpenuhi. Untuk menghitung daya dan putaran yang diperlukan pada proses pencukilan menggunakan rumus (5), perhatikan gambar 3 .

$\mathrm{P}_{\mathrm{B}}=\frac{2 \pi \mathrm{n}_{\mathrm{B}} \mathrm{T}_{\mathrm{B}}}{60}$ Watt

Keterangan :

$\mathrm{P}_{\mathrm{B}}=$ daya yang diperlukan untuk pencukilan [Watt]

$\mathrm{T}_{\mathrm{B}}=$ momen putar pencukilan [kgf], didapat dari gaya tusuk maksimum hasil uji coba dikalikan dengan jari-jari buah kelapa

$\mathrm{n}_{\mathrm{B}}=$ putaran belahan kelapa yang diperlukan[rpm],didapat dari perhitungan kapasitas perdetik yang diinginkan

Roda gigi payung nomor 10 (lihat gambar 3) seporos dengan pencekam belahan kelapa untuk proses pencukilan, maka daya $\mathrm{P}_{10}=\mathrm{P}_{\mathrm{B}}$, demikian putarannya $n_{10}=n_{B}$. kemudian menghitung putaran dan daya roda gigi payung 9 yaitu $\mathrm{n}_{9}$ menggunakan persamaan (6) dan (7).

$$
\begin{aligned}
& \mathrm{n}_{9}=\frac{\mathrm{n}_{10} \cdot \mathrm{D}_{10}}{\mathrm{D}_{9}} \\
& \mathrm{P}_{9}=\frac{\mathrm{P}_{10}}{\eta_{\mathrm{B}}}
\end{aligned}
$$

Selanjutnya daya dan putaran roda gigi pada gear box dihitung dengan persamaan (8) dan (9).

$$
\mathrm{P}_{8}=\frac{\mathrm{P}_{9}}{\eta_{\mathrm{C}}}
$$

$\mathrm{n}_{8}=\mathrm{i} . \mathrm{n}_{9}$

Keterangan :

$\eta_{\mathrm{A}}$ adalah efisiensi transmisi proses pembelahan buah kelapa menggunakan sabuk puli sehingga diambil $\eta_{\mathrm{A}}=0,75$

$\eta_{\mathrm{B}}$ merupakan efisiensi transmisi gear box $1: 40$ yaitu $\eta_{\mathrm{B}}=0,75$

$\eta_{\mathrm{C}}$ efisiensi transmisi roda gigi payung $\eta_{\mathrm{C}}=0,75$ 
d. Langkah terakhir perhitungan daya dan putaran motor listrik menggunakan persamaan (10) dan (11).

$\mathrm{P}_{\mathrm{M}}=\mathrm{P}_{6}+\mathrm{P}_{8}$

$\mathrm{n}_{\mathrm{M}}=\mathrm{n}_{4}+\mathrm{n}_{8}$

\section{HASIL DAN PEMBAHASAN}

3.1 Daya dan putaran yang dibutuhkan untuk proses pembelahan buah

\section{kelapa}

Diameter buah kelapa $\mathrm{d}=260[\mathrm{~mm}]$ diinginkan dapat terbelah menjadi dua bagian yang sama dalam satu putaran gergaji, maka diameter gergaji $\mathrm{D}=300$ $[\mathrm{mm}]$, dan putaran piringan gergaji $\mathrm{n}_{\mathrm{A}}$ ditentukan dengan persamaan 1 , sedangkan daya $\mathrm{P}_{\mathrm{A}}$ dengan persamaan 2 .

$$
\begin{aligned}
& \mathrm{n}_{\mathrm{A}}=16,6 \mathrm{rpm} \\
& \mathrm{T}_{\mathrm{A}}=\text { momen putar }[\mathrm{Nm}]=475 \cdot 150 \cdot 10^{-3}=71,25[\mathrm{kgf} \mathrm{m}] \\
& \mathrm{P}_{\mathrm{A}}=\frac{2 \cdot 3,14 \cdot 16,6 \cdot 71,25}{60}=123,8[\text { Watt }]
\end{aligned}
$$

Karena gergaji satu poros dengan puli 4 yang berdiameter $\mathrm{D}_{4}$, maka $\mathrm{n}_{4}=$ $16,6 \mathrm{rpm}$, daya $\mathrm{P}_{4}=123,8$ [Watt], sehingga putaran pada puli 6 berdiameter $\mathrm{D}_{6}$ yaitu $\mathrm{n}_{6}$ menggunakan persamaan (3) dan daya persamaan (4) :

$\mathrm{n}_{6}=249 \mathrm{rpm}$, dan $\eta=0,75$

maka daya $\mathrm{P}_{6}=\frac{123,8}{0,75}=165[\mathrm{Watt}]$

\subsection{Daya dan putaran untuk proses pencukilan putih lembaga.}

Belahan kelapa berputar satu kali, pemakanan pisau pencukil $\mathrm{s}=13[\mathrm{~mm}]$, sedangkan tinggi belahan buah kelapa $h=130[\mathrm{~mm}]$, sehingga membutuhkan 10 kali putaran untuk satu buah belahan kelapa. Sedangkan waktu satu kali putaran adalah $\mathrm{t}=1,4$ detik, maka putaran $\mathrm{n}_{\mathrm{B}}=83 \mathrm{rpm}$. Momen putar $\mathrm{T}_{\mathrm{B}}=475.130 .10^{-3}$ $=61,75[\mathrm{kgf} \mathrm{m}]$, dan daya yang dibutuhkan untuk proses pencukilan menggunakan persamaan (5) yaitu $P_{B}=107,3$ [Watt]. Roda gigi payung 10 satu poros dengan pencekam belahan kelapa sehingga putarannya $\mathrm{n}_{10}=83 \mathrm{rpm}$, dan daya $P_{10}=107,3$ [Watt], sedangkan putaran pada roda gigi payung 9 dengan harga $\mathrm{i}=4$ maka $\mathrm{n}_{9}$ menggunakan persamaan (6), $\mathrm{n}_{9}=332 \mathrm{rpm}$. Sedangkan daya persamaan (7) $\mathrm{P}_{9}=143$ [Watt], selanjutnya daya dan putaran roda gigi penggerak pada gear box adalah $\mathrm{n}_{8}=3.332=996 \mathrm{rpm}, \mathrm{P}_{8}=\frac{143}{0,75}=190,7$ [Watt] yang digunakan adalah persamaan (8) dan (9).

\subsection{Daya dan putaran motor listrik sebagai tenaga penggerak.}

Mekanisme kerja mesin menggunakan satu buah motor listrik untuk menggerakkan dua proses pekerjaan yaitu pembelahan dan pencukilan melalui transmisi sabuk puli memutar gergaji dengan efisiensi $\eta_{\mathrm{A}}=0,75$, dan untuk memutar belahan kelapa menggunakan dua tingkat transmisi yaitu roda gigi 
payung dan gear box $1: 40$ dengan efisiensi masing-masing $\eta_{\mathrm{B}}=0,75, \eta_{\mathrm{C}}=0,75$, sehingga daya motor listrik dihitung menggunakan persamaan (10) dan (11).

$\mathrm{P}_{\mathrm{M}}=\mathrm{P}_{6}+\mathrm{P}_{8}=165+190,7=356$ [Watt]., dan putaran motor listrik $\mathrm{n}_{\mathrm{M}}=\mathrm{n}_{4}+$ $\mathrm{n}_{8}=249+996=1245 \mathrm{rpm}$. Karena motor listrik sesuai standar pasar maka dipilih motor listrik $1 / 2 \mathrm{Hp}$ putaran $1450 \mathrm{rpm}$.

Mesin pembelah buah kelapa dan pemisah putih lembaga dari tempurung dapat dilihat pada gambar 5 .
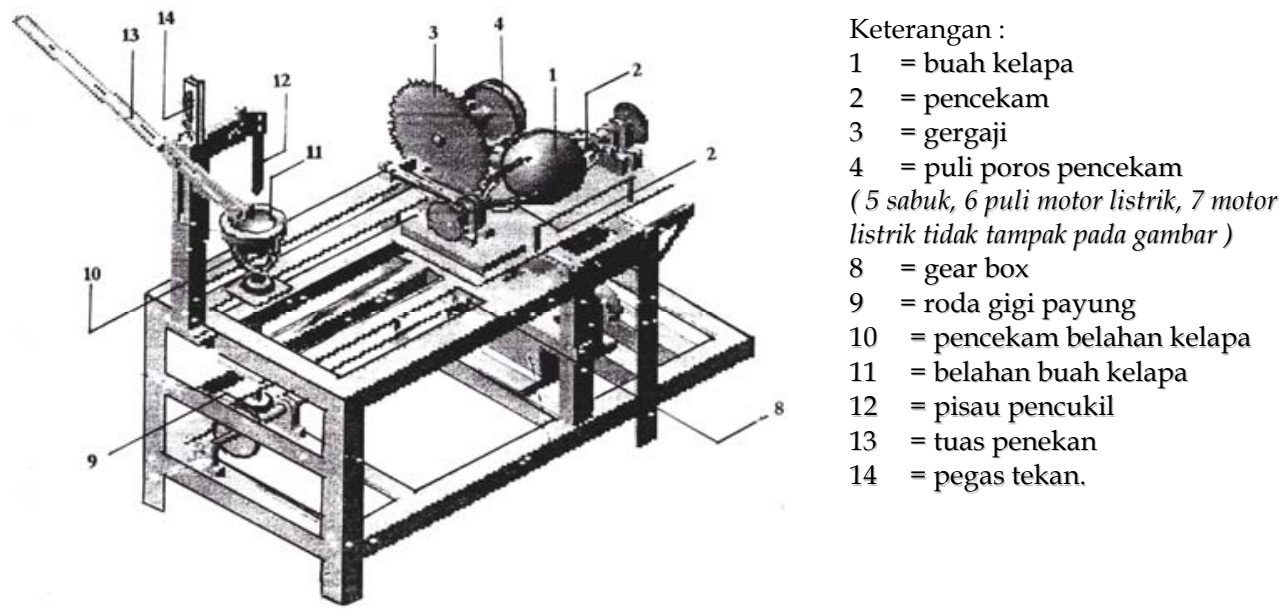

Gambar 5. Mesin Pembelah Buah Kelapa dan Pemisah Putih Lembaga dari Tempurung

Tabel 3. Spesifikasi Mesin Pemisah Daging Kelapa dari Tempurung

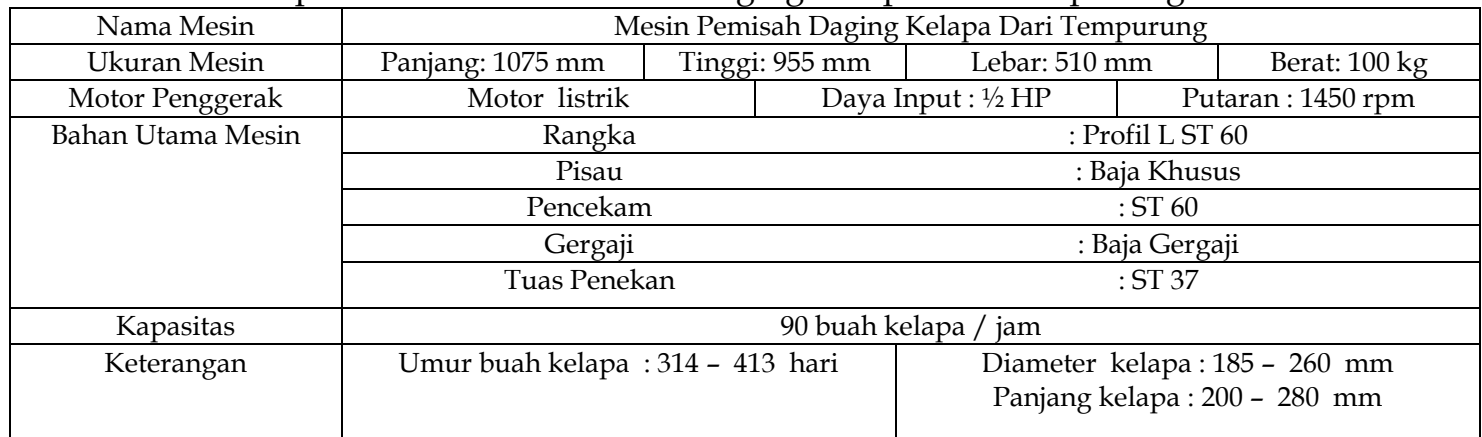

Perinsip kerja mesin adalah : Buah kelapa dicekam dengan pencekam (2) pada dua sisi dan perinsip pencekamannya menggunakan pegas tekan. Gergaji pembelah (3) berbentuk piringan (circle disk) berputar untuk membelah buah kelapa (1) menjadi dua bagian yang sama (11), putaran gergaji digerakkan langsung oleh motor listrik melalui transmisi sabuk puli. Pada saat bersamaan belahan kelapa (11) hasil proses pembelahan yang dicekam pencekam (10)diputar oleh motor listrik melalui dua tingkat transmisi yaitu gear box (8) dan roda gigi payung (9), sedangkan pisau pencukil kelapa diatur tepat diantara putih lembaga 
dan tempurung kemudian ditekan dengan tangan melalui tuas yang dilengkapi dengan pegas tekan.

Pisau terbuat dari bahan yang mudah lentur mengikuti kontur tempurung, sehingga putih lembaga dapat terpisah dengan mudah dan bersih dari tempurung, lihat gambar 6 dan data hasil pengujian mesin pada tabel 4 .

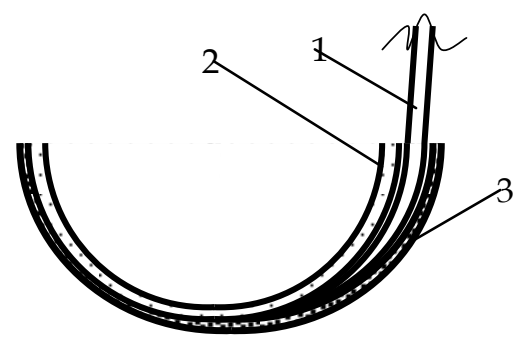

Keterangan :

1 = pisau pencukil terbuat dari bahan yang mudah

lentur mengikuti kontur tempurung.

$2=$ putih lembaga (dagingkelapa)

3 = tempurung

Gambar 6. Sketsa teknis kerja pisau pencukil

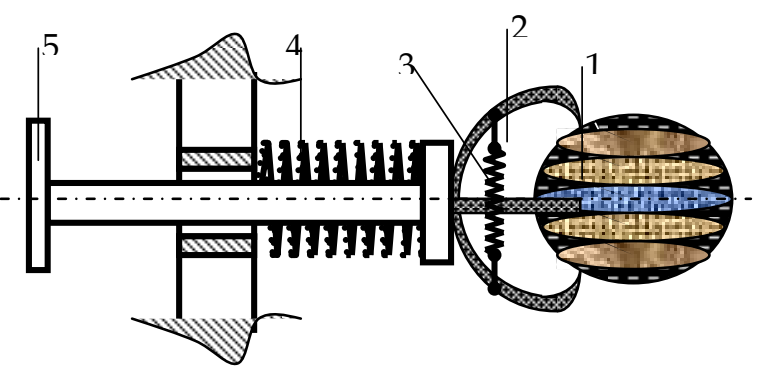

Keterangan :

1 = buah kelapa

2 = rahang pencekam

3 = pegas tarik

$4=$ pegas tekan

$5=$ tuas penarik

Gambar 7. Sketsa teknis pencekam buah kelapa

Konstruksi pencekam yang dilengkapi pegas tekan dan pegas tarik ditunjukkan pada gambar 7. Konstruksi tuas penekan untuk menekan pisau pada proses pencukilan putih lembaga dari tempurung ditunjukkan oleh gambar 8 .

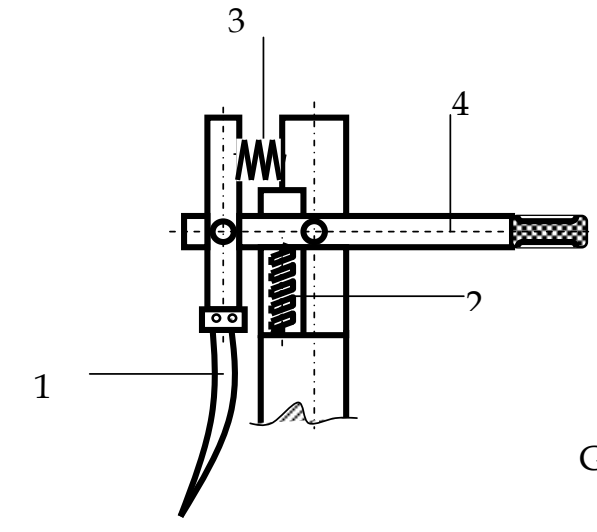

Gambar 8. Sketsa teknis kerja pisau

Tabel 4. Kapasitas Pemisahan Putih Lembaga Menggunakan

TEKNOIN, Vol. 10, No. 4, Desember 2005, 305-314

Keterangan :

$1=$ pisau lentur

$2=$ pegas tekan

$3=$ pegas tekan

$4=$ tuas penekan 
Mesin Hasil Rancang Bangun

\begin{tabular}{|c|c|c|c|c|c|c|c|c|}
\hline $\begin{array}{c}\mathrm{N} \\
\mathrm{o}\end{array}$ & $\begin{array}{l}\text { Jumlah } \\
\text { Kelapa } \\
\text { [ buah ] }\end{array}$ & $\begin{array}{c}\text { Waktu } \\
\text { Pemasangan I } \\
{[\text { det ] }}\end{array}$ & $\begin{array}{c}\text { Proses } \\
\text { Pembelahan } \\
\text { [ det ] }\end{array}$ & $\begin{array}{c}\text { Waktu } \\
\text { Pelepasan I } \\
\text { [ det ] }\end{array}$ & $\begin{array}{c}\text { Waktu } \\
\text { Pemasangan } \\
\text { II } \\
\text { [ det ] }\end{array}$ & $\begin{array}{c}\text { Proses } \\
\text { Pencukilan } \\
\text { [ det ] }\end{array}$ & $\begin{array}{c}\text { Waktu } \\
\text { Pelepasan } \\
\text { II }\end{array}$ & $\begin{array}{c}\text { Total } \\
\text { Waktu } \\
\text { [ det ] }\end{array}$ \\
\hline 1 & 1 & 6 & 8 & 6 & 6 & 8 & 6 & 40 \\
\hline 2 & 1 & 6 & 7 & 8 & 6 & 7 & 6 & 40 \\
\hline 3 & 1 & 6 & 7 & 7 & 6 & 8 & 6 & 40 \\
\hline 4 & 1 & 6 & 8 & 6 & 6 & 8 & 6 & 40 \\
\hline 5 & 1 & 6 & 7 & 7 & 6 & 8 & 6 & 40 \\
\hline
\end{tabular}

\section{SIMPULAN}

Kapasitas mesin pemisahan putih lembaga dari tempurung menggunakan mesin hasil rancang bangun ini adalah 1 buah kelapa setiap 40 detik artinya 90 buah/jam, yang terdiri dari dua proses kerja, yaitu kerja pembelahan dan kerja pencukilan. Sedangkan kualitas putih lembaga bersih dari tempurung, sudah jauh lebih baik dari cara manual yaitu sisa tempurung tidak ada yang menempel pada putih lembaga. Mesin cukup dioperasikan oleh satu orang tenaga kerja, dan mesin mudah diduplikasi karena konstruksinya sederhana. Tenaga penggerak mesin adalah motor listrik $1 / 2 \mathrm{Hp}$ dan putaran $1450 \mathrm{rpm}$ yang didapat melalui perhitungan, demikian pula dimensi, transmisi dibuat melalui perhitungan dengan memperhatikan keadaan industri rumah tangga yang bermodal kecil.

Dalam mengoperasikan mesin perlu memperhatikan umur buah kelapa agar pemisahan putih lembaga dari tempurung dapat menghasilkan putih lembaga yang bersih dari sisa tempurung, dan umur buah kelapa yang disarankan berumur 314 - 413 hari dari berbagai jenis buah kelapa.

\section{PUSTAKA}

[1] Anonim, (1991) Teknologi Tepat Guna untuk Wanita di Pedesaan. Cetakan I Kantor Urusan Peranan Wanita bekerjasama dengan Unicef, Jakarta

[2] Herman,A.S, Paradiyato, M.S. dan Sukawi F.X, (1997) Pemisahan Minyak dan Protein dari daging Kelap Cara Churning, Komunikasi No.186 BPK, Bogor.

[3] Hagenmaier,R.C.M.Cartet and K.F. Mattil, (1993) Aqueous Processing of Fresh Coconut for Recovery of oil and Coconut Skim Milk, Journal of Food Science, Singapura

[4] Puertollano, C.L.J.Banzon and K.H Steinkraus, (1990) Separation of the Oil and Protein Practions in Coconut (Coeos Nucifera LINN) by Fermentatio, Journal Of Agrieultural and Chemestry, England

[5] Sularso dan Kiyokatsu. S, (1997) Dasar Perencanaan dan Pemilihan Elemen Mesin, Cetakan ke II PT. Pradnya Paramita, Jakarta

[6] Sukrisno, Umar, (1994) Bagian-Bagian Merencana Mesin, Cetakan ke 4, PT Grafitas Offset Erlangka, Jakarta 